\title{
Evaluation of anti-arthritic and anti- inflammatory activities of Martynia annua L. Ethanolic extract
}

\author{
Suruj Kaushik', Parag Jain², Trilochan Satapathy ${ }^{1 *}$, Prerna Purabiya ${ }^{1}$ and Amit Roy ${ }^{1}$
}

\begin{abstract}
Background: Arthritis is a disorder of change in joint architecture and ligament degeneration. Rheumatoid arthritis is an autoimmune disorder in which body's immune system targets own cells and degrade them. Martynia annua L. has been used in Indian traditional therapies for the treatment of epilepsy, many types of inflammations, respiratory infection, sore throat and wound. The objective of the present study was to determine antiinflammatory and anti-arthritic activities of $M$. annua ethanolic fruit extract.

Methods: The extraction was performed using ethanol as a solvent followed by phytochemical investigation of $M$. annua ethanolic fruit extract. Antioxidant and anti-hyaluronidase enzyme inhibition activities was performed for the fruit extract. In vivo anti-inflammatory of fruit extract was performed on Calotropis procera latex (CPL) induced paw edema in rats using ibuprofen as standard. Inflammation was observed at 0, 1, 2, 4 and $6 \mathrm{~h}$. In vivo anti-arthritic of fruit extract was performed on Complete Freund's adjuvant (CFA) induced arthritis in rats. Arthritis was observed at 0, 7, 14 and 21 day. X-Ray study was also performed for inflammatory and arthritic paw of rats.
\end{abstract}

Results: The qualitative phytochemical screening of fruit extract showed presence of flavonoids, terpenoids, saponins, tannins, steroids, glycosides, proteins, carbohydrates, amino acids and polysaccharides. The antioxidant activity of fruit extract was 49.1 as compared to standard 45.73 at $100 \mu \mathrm{l}$ dose. The anti-hyaluronidase enzyme inhibition activity of fruit extract was 84.60 as compared to standard 94.21 at $100 \mu \mathrm{l}$ dose.

Conclusion: It is evident from the study that Martynia annua L. extract possess both antioxidant and hyalurinodase inhibition activity at dose dependent manner as well as anti-arthritic and anti-inflammatory potential.

Keywords: Martynia annua, Inflammation, Arthritis, Calotropis procera, Hyaluronidase

\section{Background}

Arthritis comprises varieties of joint disorders such as rheumatoid arthritis (RA), Osteoarthritis (OA) etc. those affect one joint or multiple joints [1]. Arthritis can be develop in anyone irrespective of gender, age and race [2]. The common symptoms of arthritis include swelling, tenderness and stiffness of joints as well as decrease the range of motions. It can be ranged from mild to severe conditions [3]. Person suffering from severe arthritis

\footnotetext{
* Correspondence: drtsatapathy@gmail.com

${ }^{1}$ Columbia Institute of Pharmacy, Tekari, Near Vidhansabha, Raipur,

Chhattisgarh 493111, India

Full list of author information is available at the end of the article
}

shows inability to walk and move as well as unable to perform daily activities [4]. It can cause permanent damage of joint architecture and degeneration of ligament [5]. RA is a systematic autoimmune disorder in which host's immune system targets their own cells [6]. RA has been showing a global threat to many many healthy individuals. However, in India nearly $15 \%$ population i.e. 180 million people are affected from RA [7]. The prevalence of RA is higher than other diseases like cancer and diabetes. It has reported that arthritis is ranked as second most common cause of disability and considered as a significant contributor to global disability burden [8].

\section{Springer Open}

(c) The Author(s). 2021 Open Access This article is licensed under a Creative Commons Attribution 4.0 International License, which permits use, sharing, adaptation, distribution and reproduction in any medium or format, as long as you give appropriate credit to the original author(s) and the source, provide a link to the Creative Commons licence, and indicate if changes were made. The images or other third party material in this article are included in the article's Creative Commons licence, unless indicated otherwise in a credit line to the material. If material is not included in the article's Creative Commons licence and your intended use is not permitted by statutory regulation or exceeds the permitted use, you will need to obtain permission directly from the copyright holder. To view a copy of this licence, visit http://creativecommons.org/licenses/by/4.0/. 
The incidence of RA is progresses with age and the peak is observed between the age groups of 35 and 50 years. Further the research data revealed that the globally incidence of RA is estimated as 3 in each 10,000 people [9]. The conventional treatment options for RA available in the market are analgesics, Non-steroidal anti-inflammatory drugs (NSAIDs), Disease-modifying anti-rheumatic drugs (DMARDs), and Corticosteroids. However, these drugs are accompanying with certain adverse effects such as gastro intestinal upset, ulcer and bleeding [10]. On the other hand, Phytotherapy is the oldest system of medicine in the world and it has been practiced in rural areas of India since a long time ago [11].

According to the report of World Health Organization (WHO), nearly $80 \%$ of the total population of Africa and china depend on traditional therapies and herbal based remedies [12]. Herbal based therapies occupied the highest share of the international market, with annual turnover billion dollars in Western Europe as well as in China [12]. The most frequency use of herbal medicines is due to failure of conventional therapies and their side effects [13-17]. Herbal medicinal drugs possess numerous qualities in the treatment of several disorders [1821]. Martynia annua L. belongs to family Martyniaceae or (Pedaliaceae). It is a small, herbaceous and annual plant, distributed all over the India. It is also known as the Cat's claw. In Ayurvedic scriptures, it is called as kakanasika, which is generally being used in Indian traditional therapies for the treatment of epilepsy, tuberculosis, sore throat and wound [22]. Interestingly, the fruits of $M$. annua are useful in inflammation and burns. Seeds oils are used in itching and skin affections. The fruit of $M$. annua is also used for its local sedative action. Thus, the primary aim of this research was to evaluate the anti-arthritic and anti-inflammatory potential of $M$. annua fruit extract.

\section{Materials and methods}

\section{Chemicals and reagents}

Picric acid was purchased from Fizmerk India Chemicals, UP, India, Complete Freund's adjuvant was procured from Sigma-Aldrich, USA, Halothane from Korten Pharmaceutical Pvt. Ltd., Ethanol and Carboxy methyl cellulose from Loba chemie, USA, Indomethacin from Jagsonpal Pharmaceuticals Pvt. Ltd. India and Ibuprofen was procured from Abbott India Ltd. All chemical and reagents use in the study were of analytical grade.

\section{Collection, identification authentication and extraction of Martynia annua L. fruit}

The fruits of $M$. annua were collected from village Tekari of Raipur, Chhattisgarh, India in December 2018 and authenticated by Dr. Ravindra Kumar Pandey,
Professor, Dept. of Pharmacognosy; Columbia Institute of Pharmacy (CIP), Raipur, Chhattisgarh, India. The sample specimen was deposited in the herbarium of the institute wide voucher no. 0.213 . The fruits were washed in running tap water; dried (360 g), crushed into coarse powder and soaked using 4.4 L of ethanol for period of 3 weeks. The extraction process with ethanol was repeated three times at room temperature by using soxhlet apparatus. The extract was distilled under reduced pressure andcontrolled temperature $\left(40-50{ }^{\circ} \mathrm{C}\right)$ after extraction. The resulting semisolid residue or extract was evaporated using water bath andextract of $M$. annua fruit was filtered. It was then kept in an airtight dark colored container and stored in a refrigerator. The percentage yield of the extract was $19.30 \%$.

\section{Phytochemical analysis of $M$. annua fruit extract}

Following tests were performed for $M$. annua fruit extract to determine presence of phytochemicals:

\section{Test for carbohydrates}

Molisch Test: Test sample was prepared by dissolving 1 $\mathrm{g}$ of dried ethanolic extract of $M$. annua with $10 \mathrm{ml}$ of water. To the $2 \mathrm{ml}$ of sample, $2 \mathrm{ml}$ of alpha-napthol was added and mixed carefully, however, the concentrated $\mathrm{H}_{2} \mathrm{SO}_{4}$ was added along side of the walls to the test tubes, carefully. The purple violet coloured rings were observed in between the junction of the two layers confirmed the presence of carbohydrate [23, 24].

\section{Test for glycosides}

Test sample was prepared by dissolving $1 \mathrm{~g}$ of dried ethanolic extract of $M$. annua with $10 \mathrm{ml}$ of water. To the $1 \mathrm{ml}$ of test sample solution, $3 \mathrm{ml}$ of anthronone reagent was added and mixed well carefully. The formation of green coloured complex indicated the presence of glycoside [25].

\section{Test for polysaccharides}

Test sample was prepared by dissolving $1 \mathrm{~g}$ of dried ethanolic extract of $M$. annua with $10 \mathrm{ml}$ of water. To 1 $\mathrm{ml}$ of test sample, 2 drops of iodine solution was added. Appearance of blue coloured solution indicated the presence of polysaccharides [26].

\section{Test for free amino acids}

Test sample was prepared by dissolving $1 \mathrm{~g}$ of dried ethanolic extract of $M$. annua with $10 \mathrm{ml}$ of water. To 1 $\mathrm{ml}$ of test sample add 5 drops of ninhydrin and boil for 2 min. Appearance of purple coloured solution indicated the presence of amino acids [27]. 


\section{Bradford's test}

Test sample was prepared by dissolving $1 \mathrm{~g}$ of dried ethanolic extract of $M$. annua with $10 \mathrm{ml}$ of water. To $0.5 \mathrm{ml}$ of test sample solution, dragendroffs reagent (3 $\mathrm{ml}$ ) was added, the appearance of blue color indicated the presence of protein [25].

\section{Test for alkaloids}

Test sample was prepared by dissolving $1 \mathrm{~g}$ of dried ethanolic extract of $M$. annua with $10 \mathrm{ml}$ of water. To 3 $\mathrm{ml}$ of sample dragendroff's reagent was added and mixed well. It was then boiled for 5 mins. The appearance of dark brown or orange colour indicated the presence of alkaloids.

To $1 \mathrm{ml}$ of sample Mayer's reagent was added and mixed well carefully. It was then boiled for 5 mins. The appearance of white or pale yellow colour indicated the presence of alkaloids [25].

\section{Test for steroids}

\section{Liberman Burchard test}

Test sample was prepared by dissolving $1 \mathrm{~g}$ of dried ethanolic extract of $M$. annua with $10 \mathrm{ml}$ of water. To 2 $\mathrm{ml}$ of sample 10 drops of acetic acid and two drops of concentrated $\mathrm{H}_{2} \mathrm{SO}_{4}$ were added and mixed well. Initially, red colour was observed followed by green colour that indicated the presence of steroids [28].

\section{Salkwoski test}

Test sample was prepared by dissolving $1 \mathrm{~g}$ of dried ethanolic extract of $M$. annua with $10 \mathrm{ml}$ of water. To 2 $\mathrm{ml}$ of sample, $2 \mathrm{ml}$ of concentrated $\mathrm{H}_{2} \mathrm{SO}_{4}$ was added and mixed vigorously. Steroids and $\mathrm{H}_{2} \mathrm{SO}_{4}$ layers separated and sample layers forms cherry red colour and acid layer forms green colour show presence of steroids [28].

\section{Test for triterpenes}

Test sample was prepared by dissolving $1 \mathrm{~g}$ of dried ethanolic extract of $M$. annua with $10 \mathrm{ml}$ of water. To 2 $\mathrm{ml}$ of test sample, chloroform and concentrated $\mathrm{H}_{2} \mathrm{SO}_{4}$ were added and mixed well. The appearance of red color indicated the presence of triterpenes [29].

\section{Test for flavonoids}

Test sample was prepared by dissolving $1 \mathrm{~g}$ of dried ethanolic extract of $M$. annua with $10 \mathrm{ml}$ of water. To 1 $\mathrm{ml}$ of sample $2 \mathrm{ml}$ of $\mathrm{H}_{2} \mathrm{SO}_{4}$ was added, mixed well. The appearance of yellow colour indicated the presence of flavonoids [30].

\section{Shinoda test}

Test sample was prepared by dissolving $1 \mathrm{~g}$ of dried ethanolic extract of $M$. annua with $10 \mathrm{ml}$ of water. To the ethanolic extract sample $(2 \mathrm{ml}), 5 \mathrm{ml}$ of $95 \%$ ethanol was added along with few drops of conc. $\mathrm{HCl}$. To this solution $0.5 \mathrm{~g}$ of magnesium turnings were added. The appearance of pink colour indicated presence of flavonoids [31].

\section{Tests for tannins}

\section{$\mathrm{FeCl}_{3}$ solution test}

Test sample was prepared by dissolving $1 \mathrm{~g}$ of dried ethanolic extract of $M$. annua with $10 \mathrm{ml}$ of water. To the $2 \mathrm{ml}$ of test sample, $5 \% \mathrm{FeCl}_{3}$ Solution was added and mixed well. The appearance of deep blue black color indicated presence of tannins [32].

\section{Dil. $\mathrm{HNO}_{3}$ test}

Test sample was prepared by dissolving $1 \mathrm{~g}$ of dried ethanolic extract of $M$. annua with $10 \mathrm{ml}$ of water. To the $2 \mathrm{ml}$ of test sample, small quantity of $\mathrm{HNO}_{3}$ Solution was added and mixed well. The appearance of reddish color indicated the presence of tannins [32].

\section{Test for lipid}

Test sample was prepared by dissolving $1 \mathrm{~g}$ of dried ethanolic extract of $M$. annua with $10 \mathrm{ml}$ of water. To 2 $\mathrm{ml}$ of test sample, iodine solution was added drop wise. The disappearance of of iodine color indicated the presence of lipids [33].

\section{Test for oils}

Test sample was prepared by dissolving $1 \mathrm{~g}$ of dried ethanolic extract of $M$. annua with $10 \mathrm{ml}$ of water. The 1 drop of sample was placed on a filter paper and allowed to dry. The formation of clear greasy spot indicated the presence of oils [34].

\section{Test for saponins}

Test sample was prepared by dissolving $1 \mathrm{~g}$ of dried ethanolic extract of $M$. annua with $10 \mathrm{ml}$ of water. Few drops of sample was heated with alcoholic $\mathrm{KOH}$ and then boiled for $1 \mathrm{~min}$ followed by cooling. It was then acidified with $1 \mathrm{ml}$ of conc. $\mathrm{HCl}$. Further, a portion of it was treated with $10 \mathrm{ml}$ of water and $5 \% \mathrm{NaOH}$ was added drop wise. The formation of clear soap indicated the presence of saponins [32].

\section{Total antioxidant capacity}

The total antioxidant capacity of $M$. annua was determined by taking various concentrations of samples i.e. $10 \mu \mathrm{g}, 50 \mu \mathrm{g}$ and $100 \mu \mathrm{g}$ in a clean and dry test tubes. To the test tubes, $1.9 \mathrm{~mL}$ of reagent solution containing 0.6 $M$ sulfuric acid, $28 \mathrm{mM}$ sodium phosphate, and $4 \mathrm{mM}$ ammonium molybdate were added. The tubes were then subjected for incubation at $95^{\circ} \mathrm{C}$ for a time period of 90 min then allowed to cool. The absorbance of the aqueous solution was observed at $695 \mathrm{~nm}$ against blank. 
Antioxidant capacities of test samples were expressed as equivalents of ascorbic acid. Ascorbic acid equivalents were calculated by using standard graph of ascorbic acid. Butylated hydroxy anisole was used as reference standard in this experiment. The values were expressed as ascorbic acid equivalents in $\mu \mathrm{g}$ per $\mathrm{mg}$ of extract [35].

\section{Hyaluronidase inhibition activity}

In this assay medium consisting of 3-5 $\mathrm{U}$ hyaluronidase, $100 \mu \mathrm{l}$ of $20 \mathrm{mM}$ sodium phosphate buffer (pH 7.0), 77 $\mathrm{mM}$ sodium chloride, $0.01 \%$ Bovine Serum Albumin were added. The mixture was pre-incubated with various concentrations such as $10 \mu \mathrm{g}, 50 \mu \mathrm{g}$ and $100 \mu \mathrm{g}$ of the test compound for $15 \mathrm{~min}$ time period by maintaining temperature at $37^{\circ} \mathrm{C}$. The assay was commenced after addition of $100 \mu \mathrm{l}$ hyaluronic acid and $0.03 \%$ of $300 \mathrm{mM}$ sodium phosphate ( $\mathrm{pH} 5.35)$ to the incubation mixture. It was then allowed to incubate again for $45 \mathrm{~min}$ at temperature $37^{\circ} \mathrm{C}$. However, the undigested hyaluronic acid was precipitated with $1 \mathrm{ml}$ acid albumin solution made up of $0.1 \%$ bovine serum albumin in $24 \mathrm{mM}$ sodium acetate and $79 \mathrm{mM}$ acetic acid ( $\mathrm{pH} 3.75)$. The absorbance of the reaction mixture was measured at $600 \mathrm{~nm}$ after standing the reaction mixture at room temperature for a period of $10 \mathrm{~min}$. The absorbance in the absence of enzyme was used as the reference standard for maximum inhibition. The inhibitory potential of $M$. annua fruit extract was calculated as the percentage ratio of the absorbance in the presence of test compound vs. absorbance in the absence of enzyme. The enzymatic activity was measured by control experiment run simultaneously in which the enzyme was preincubated with $5 \mu \mathrm{l}$ DMSO instead, and followed by the assay procedures described above. Indomethacin was used as a reference drug in this experiment [36].

\section{In vivo anti-inflammatory and anti-arthritic activities Experiment animals}

Albino wistar rats weighing between 150 and $200 \mathrm{~g}$ of both sex were procured from Institutional animal house facility, Columbia Institute of Pharmacy, Raipur (C.G.). The protocol was reviewed by the expert committee (IAEC), considered and approved (Approval No is CIP/ IAEC/2017/103 and Regd.No.1321/PO/ReBi/S/10/ CPCSEA, Dated 22/10/2014). The animals were allowed for acclimatization for a period of two weeks before starting of the experiments. They were housed in the polypropylene cages with husk bedding. Standard pelleted diet and aqua guard water were provided to the animals during entire experimental duration. All animals were maintained with controlled environment, $12 \mathrm{~h}$ light/ $12 \mathrm{~h}$ dark cycle and relative humidity were maintained according to CPCSEA guidelines. The animals were examined at regular intervals for behavioral abnormalities if any.

\section{Acute toxicity study}

The toxicity potential of the test compound was evaluated according to OECD guideline 423.

\section{Screenings of anti-inflammatory activity}

\section{Calotropis procera latex (CPL) induced paw edema in rats}

Calotropis procera latex (CPL) was collected from tissues of plant stem by making an incision. CPL was centrifuged at $5000 \times \mathrm{g}$ and supernatant was isolated as sticky rubber like matter. It was dried for 2-3 days and then triturated in a mortar pestle with small amount of water to get the ready aqueous suspension of CPL for parenteral administration [37].

Albino wistar rats weighing 150-200 g were selected for the study. They were divided into five groups each containing six animals. Group 1 was negative control group, received vehicle p.o.; Group 2 was positive control group, received $0.1 \mathrm{ml}$ of CPL injected on subplantar surface of right hind paw; Group 3 and Group 4 were test groups received 200 and $400 \mathrm{mg} / \mathrm{kg}$ plant extract, respectively; and Group 5 was reference group, received ibuprofen $(72 \mathrm{mg} / \mathrm{kg})$. All rats were injected with $0.1 \mathrm{ml}$ of CPL in normal saline into sub planter area of right hind paw. Test substance and standard drug were administered $1 \mathrm{~h}$ prior to CPL injection [38].

\section{Complete Freund's adjuvant (CFA) induced arthritis in rats}

Albino wistar rats weighing 150-200 g were selected for the study. They were divided into five groups each containing six animals. Group 1 was negative control group, received vehicle p.o.; Group 2 was positive control group, received $0.1 \mathrm{ml}$ of CFA emulsion injected on subplantar surface of right hind paw; Group 3 and Group 4 were test groups received 200 and $400 \mathrm{mg} / \mathrm{kg}$ plant extract, respectively; and Group 5 was reference group, received indomethacin $(10 \mathrm{mg} / \mathrm{kg})$. Arthritis was induced by sub-plantar injection of $0.1 \mathrm{ml}$ of CFA on right hind paw of rats [39].

\section{Assessment of inflammation and arthritis}

Test drug was administered p.o. once a day from the day of injection of induction and continued up to 14 days after treatment. The assessment of inflammation and arthritis was done on following parameters:

Paw volume: The change in the inflammatory reaction was measured using mercury plethysmograph on 0,7 , 14, and 21 day from the day of induction.

Body Weight: The change in the body weight was calculated using digital weighing balance on $0,7,14$, and 21 day from the day of induction. 


\section{$X$-ray study of arthritic paw of rats}

X-ray study of paw was performed to determine the protective effect of $M$. апnиa fruit extract at the completion of dosing schedule. The two animals from each groups in CFA induced arthritis model were selected for X-ray examination. The animals were anesthetized with halothane before X-ray examination and then paw was placed on the smooth surface to take X-ray photograph using portable digital X-ray apparatus [40].

\section{Statistical analysis}

The data were expressed as mean \pm SEM for each of the parameters studied and were analyzed using One-Way ANOVA by Graph pad INSTAT, and Post hock analysis were done followed by Dunnet's test. $P<0.05$ was considered to be statistically significant.

\section{Results}

\section{Phytochemical analysis}

The result of qualitative Phytochemical screening of fruit extracts of M. апnиa are represented in Table 1 . Results

Table 1 Phytochemical analysis of fruit extracts of Martynia annua

\begin{tabular}{ll}
\hline Tests & Inference \\
\hline Carbohydrates & + \\
Glycosides & + \\
Polysaccharides & - \\
Tests for Proteins & + \\
Free amino acids & - \\
Bradford test & + \\
Tests for alkaloids & + \\
Dragendroff's test & + \\
Mayer's test & + \\
Tests for steroids & - \\
Libermann-Burchard test & - \\
Salkowski's test & - \\
Triterpenoids & + \\
Tests for flavonoids & - \\
Shinoda test & - \\
With sodium & - \\
Hydroxide & - \\
Tests for Tannins & - \\
FeCl3 test & - \\
Dilute HNO3 test & - \\
Test For Lipid & - \\
Test for Oils & - \\
\hline &
\end{tabular}

(+) positive, (-) negative
Table 2 Total antioxidant activity of fruit extract of Martynia annua

\begin{tabular}{lll}
\hline Concentration & Sample (\%) & BHA (\%) \\
\hline $10 \mu \mathrm{l}$ & 32.05 & 8.18 \\
$50 \mu \mathrm{l}$ & 39.15 & 29.9 \\
$100 \mu \mathrm{l}$ & 49.1 & 45.73 \\
\hline
\end{tabular}

showed the presence of several secondary metabolites such as flavonoids, tannins, steroids, terpenoids, saponins, glycosides, Proteins, carbohydrates, amino acids, and polysaccharides in plant extract. However, flavonoids and tannins were the major groups of compounds that act as primary antioxidants or free radical scavengers.

\section{Total antioxidant capacity}

Table 2 representing the total anti oxidant capacity of the $M$. апnиa fruit extract at different concentrations i.e. $10 \mu \mathrm{l}, 50 \mu \mathrm{l}$ and $100 \mu \mathrm{l}$. The extract at $100 \mu \mathrm{l}$ showing total antioxidant activity i.e. 49.1 as compared to standard BHA i.e. 45.73. The antioxidant capacities were expressed as equivalents of ascorbic acid and Butylated hydroxy anisole (BHA) which was used as a reference standard. The values were expressed as ascorbic acid equivalents in $\mu \mathrm{g}$ per $\mathrm{mg}$ of extract. The absorbance of the aqueous solution of each sample was measured at $695 \mathrm{~nm}$ against a blank. This analysis showed an increase in total antioxidant capacity with increase in concentration of the extract.

\section{Effect of M. annua on hyaluronidase enzyme inhibition activity}

Table 3 shows the hyalurinodase inhibitory activity of $M$. annua fruit extract. The percentage inhibition of hyalurinodase enzyme by the extract at concentration of $50 \mu \mathrm{g}$ was found to be 73.66 , however, at $100 \mu \mathrm{g}$ the hyalurinodase inhibition was 84.6 in comparison to the control group. The result revealed that the fruit extract of $M$. annua at different concentration $(10 \mu \mathrm{l}, 50 \mu \mathrm{l}$ and $100 \mu \mathrm{l})$ exhibited dose dependent hyalurinodase inhibition and thus, proved to be effective as an antiinflammatory agent.

Table 3 Percentage inhibition of hyaluronidase enzyme activity by $M$. annua

\begin{tabular}{lll}
\hline Concentration & Sample (\%) & Indomethacin (\%) \\
\hline $\mathbf{1 0} \boldsymbol{\mu g}$ & 58.02 & 42.86 \\
$\mathbf{5 0} \boldsymbol{\mu g}$ & 73.66 & 87.95 \\
$\mathbf{1 0 0} \boldsymbol{\mu g}$ & 84.60 & 98.21 \\
\hline
\end{tabular}


Table 4 Effect of Martynia annua extract on CPL induced paw edema in rats

\begin{tabular}{|c|c|c|c|c|c|c|c|c|}
\hline \multirow[t]{2}{*}{$\begin{array}{l}\text { Time } \\
\text { (h) }\end{array}$} & \multicolumn{2}{|l|}{ Control } & \multicolumn{2}{|c|}{$\begin{array}{l}\text { Low dose group } \\
(200 \mathrm{mg} / \mathrm{kg})\end{array}$} & \multicolumn{2}{|c|}{$\begin{array}{l}\text { High dose group } \\
(400 \mathrm{mg} / \mathrm{kg})\end{array}$} & \multicolumn{2}{|l|}{ Standard } \\
\hline & $\begin{array}{l}\text { Initial volume } \\
(\mathrm{ml})\end{array}$ & $\begin{array}{l}\text { Final volume } \\
(\mathrm{ml})\end{array}$ & $\begin{array}{l}\text { Initial volume } \\
(\mathrm{ml})\end{array}$ & $\begin{array}{l}\text { Final volume } \\
(\mathrm{ml})\end{array}$ & $\begin{array}{l}\text { Initial volume } \\
\text { (ml) }\end{array}$ & $\begin{array}{l}\text { Final volume } \\
(\mathrm{ml})\end{array}$ & $\begin{array}{l}\text { Initial volume } \\
(\mathrm{ml})\end{array}$ & $\begin{array}{l}\text { Final volume } \\
(\mathrm{ml})\end{array}$ \\
\hline 0 & $9.06 \pm 1.01$ & $9.93 \pm 2.25$ & $8.93 \pm 0.29$ & $9.4 \pm 1.39$ & $8.91 \pm 1.12$ & $9.43 \pm 2.22$ & $8.33 \pm 0.32$ & $9.68 \pm 1.39^{* *}$ \\
\hline 1 & $9.06 \pm 0.72$ & $10.23 \pm 1.27$ & $8.93 \pm 1.93$ & $9.86 \pm 2.99$ & $8.91 \pm 0.37$ & $9.73 \pm 1.48$ & $8.33 \pm 0.49$ & $9.08 \pm 1.99^{* * *}$ \\
\hline 2 & $9.06 \pm 1.28$ & $10.26 \pm 2.03$ & $8.93 \pm 1.29$ & $9.73 \pm 2.00^{*}$ & $8.91 \pm 2.48$ & $9.71 \pm 1.44^{* *}$ & $8.33 \pm 1.47$ & $8.71 \pm 1.47^{* * * *}$ \\
\hline 4 & $9.06 \pm 1.22$ & $10.30 \pm 1.93$ & $8.93 \pm 0.38$ & $9.65 \pm 1.83^{*}$ & $8.91 \pm 2.11$ & $9.57 \pm 2.47^{* * *}$ & $8.33 \pm 2.14$ & $8.66 \pm 2.44^{* * *}$ \\
\hline 6 & $9.06 \pm 1.62$ & $10.38 \pm 1.11$ & $8.93 \pm 1.88$ & $9.56 \pm 1.77^{* *}$ & $8.91 \pm 1.36$ & $9.33 \pm 2.11^{* * *}$ & $8.33 \pm 2.08$ & $8.58 \pm 1.48^{* * *}$ \\
\hline
\end{tabular}

\section{Acute toxicity study}

The ethanolic extract of $M$. annua was found non-toxic to the animals upto $2000 \mathrm{mg} / \mathrm{kg}$ dose. No any sign of toxicity in terms of change of fur color, behavioral change, writhing response, lethargy, change in urination and feeding habits were seen upto 14 days of observation.

\section{In vivo anti inflammatory activity (CPL induced paw edema)}

In-vivo anti-inflammatory activity of $M$. annua extract was carried out using CPL induced paw edema model in rats. Effect of extract on CPL induced paw edema in rats is depicted in Table 4 and Fig. 1. Results exhibited that M. annua extract possesses better anti inflammatory

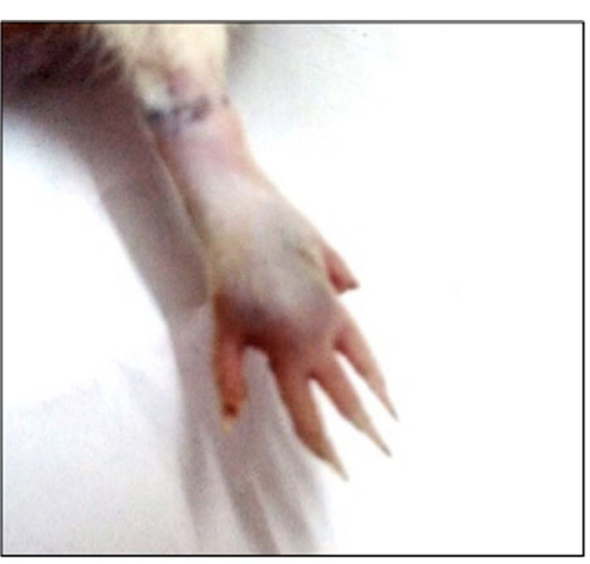

A

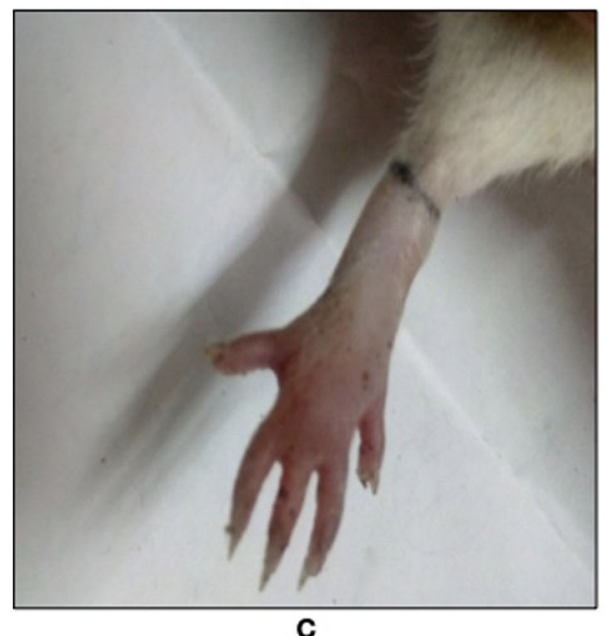

C

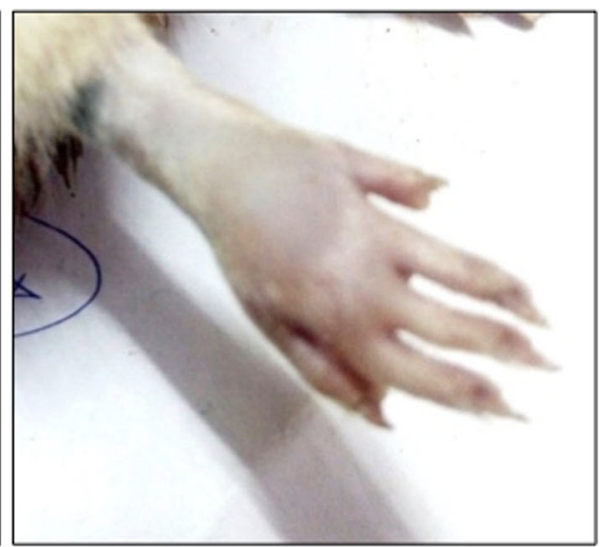

B

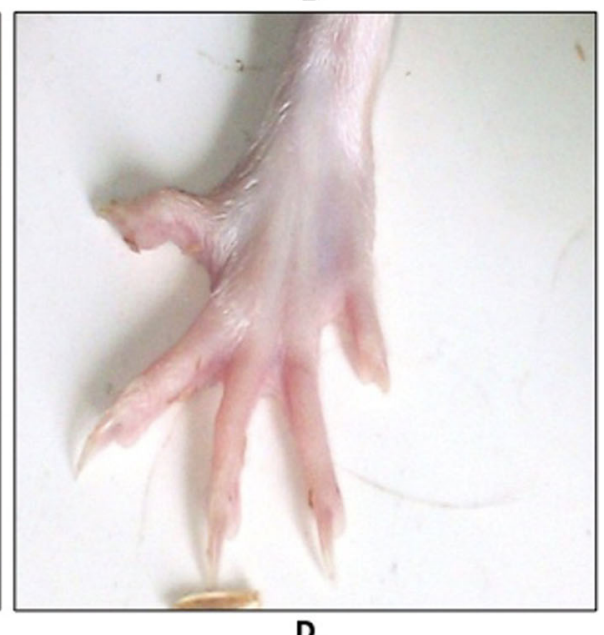

Fig. 1 Effect of Martynia annua L. extract on CPL induced paw edema in rats. $\mathbf{a}=$ Control group, $\mathbf{b}=$ Low dose group $(200 \mathrm{mg} / \mathrm{kg})$, $\mathbf{c}=$ High dose group (400 mg/kg), $\mathbf{d}$ = Standard 
Table 5 Effect of Martynia annua extract on CFA induced paw edema in rats

\begin{tabular}{|c|c|c|c|c|c|c|c|c|}
\hline \multirow[t]{2}{*}{$\begin{array}{l}\text { Time } \\
\text { (Day) }\end{array}$} & \multicolumn{2}{|l|}{ Control } & \multicolumn{2}{|c|}{$\begin{array}{l}\text { Low dose group } \\
(200 \mathrm{mg} / \mathrm{kg})\end{array}$} & \multicolumn{2}{|c|}{$\begin{array}{l}\text { High dose group } \\
(400 \mathrm{mg} / \mathrm{kg})\end{array}$} & \multicolumn{2}{|l|}{ Standard } \\
\hline & $\begin{array}{l}\text { Initial volume } \\
(\mathrm{ml})\end{array}$ & $\begin{array}{l}\text { Final volume } \\
\text { (ml) }\end{array}$ & $\begin{array}{l}\text { Initial volume } \\
\text { (ml) }\end{array}$ & $\begin{array}{l}\text { Final volume } \\
(\mathrm{ml})\end{array}$ & $\begin{array}{l}\text { Initial volume } \\
(\mathrm{ml})\end{array}$ & $\begin{array}{l}\text { Final volume } \\
(\mathrm{ml})\end{array}$ & $\begin{array}{l}\text { Initial volume } \\
(\mathrm{ml})\end{array}$ & $\begin{array}{l}\text { Final volume } \\
\text { (ml) }\end{array}$ \\
\hline 0 & $8.42 \pm 0.38$ & $8.56 \pm 1.48$ & $8.45 \pm 0.47$ & $8.56 \pm 0.44$ & $8.47 \pm 1.33$ & $8.53 \pm 1.06$ & $8.48 \pm 1.31$ & $8.50 \pm 1.38$ \\
\hline 7 & $8.51 \pm 1.39$ & $9.62 \pm 0.34$ & $9.18 \pm 1.41$ & $10.83 \pm 1.98$ & $9.56 \pm 0.22$ & $9.85 \pm 1.22^{* * *}$ & $9.6 \pm 0.66$ & $9.41 \pm 2.33^{* * *}$ \\
\hline 14 & $8.33 \pm 0.48$ & $10.31 \pm 1.48$ & $9.18 \pm 0.88$ & $10.23 \pm 1.39$ & $9.56 \pm 0.98$ & $9.95 \pm 0.65^{* * *}$ & $9.46 \pm 1.27$ & $9.35 \pm 0.37^{* * *}$ \\
\hline 21 & $9.41 \pm 1.58$ & $10.65 \pm 1.55$ & $9.18 \pm 0.38$ & $10.13 \pm 1.20^{* *}$ & $9.56 \pm 1.33$ & $9.98 \pm 0.33^{* * *}$ & $9.46 \pm 2.18$ & $9.18 \pm 1.39^{* * *}$ \\
\hline
\end{tabular}

Data are represented as mean \pm SEM $(n=5)$, significantly different at ${ }^{*} p<0.05$, ${ }^{* *} p<0.01$ and ${ }^{* * *} p<0.001$ in comparison to control

group. Standard = indomethacin

activity at high concentration than its lower dose whereas standard drug ibuprofen exhibit more significant anti-inflammatory activity than $M$. annua treated groups. Results exhibited that $M$. аnnua significantly reduced inflammation in paw at higher dose in comparison to the control group.

\section{In vivo antiarthritic activity (CFA induced arthritis)}

The arthritis in animals was induced by injection of CFA intra articularly. Effect of $M$. annua extract on CFA induced paw edema in rats is shown in Table 5 and Fig. 2. The results of antiarthritic activity revealed that the extract significantly reduced arthritis in animals i.e. 64.28 in comparison to the control group. However, reduction in arthritis was maximum by standard group.

\section{X-ray assessment of inflamed paw of rats}

The X-ray result revealed that the animals treated with high concentration of test compound showing more protection of the cartilages in compared to low

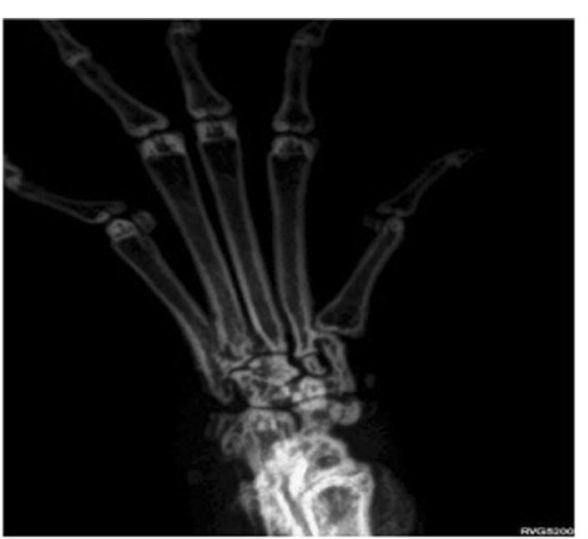

A

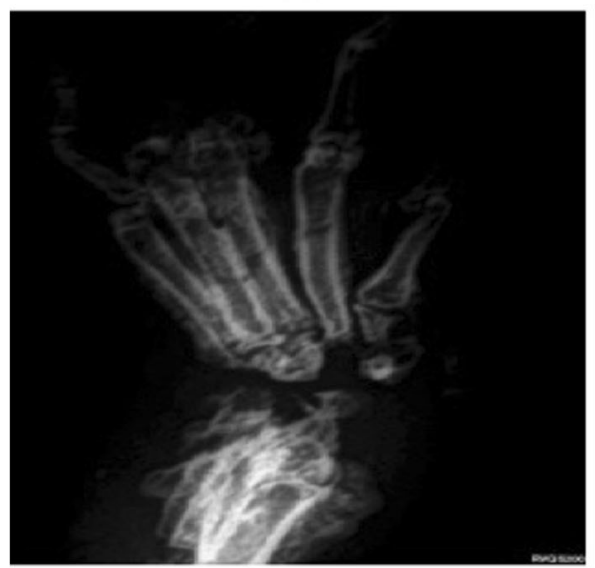

C

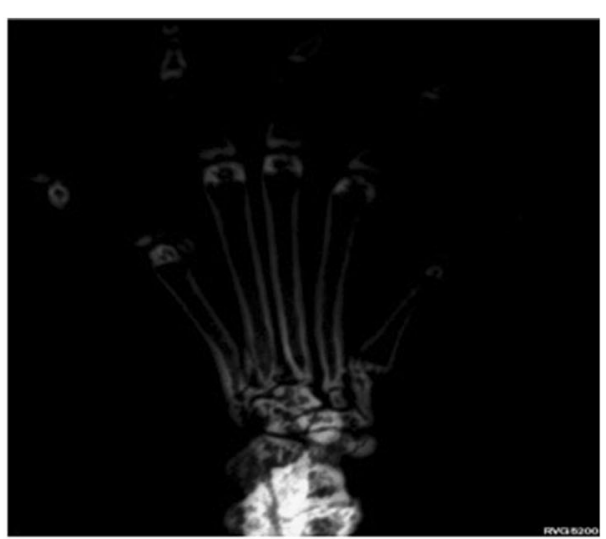

B

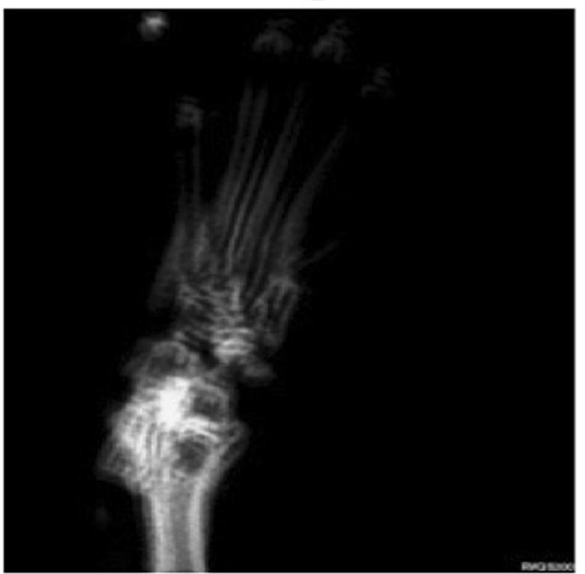

D

Fig. 2 Effect of Martynia annua L. extract on CFA induced paw edema in rats. $\mathbf{a}=$ Control group, $\mathbf{b}=$ Low dose group $(200 \mathrm{mg} / \mathrm{kg})$, $\mathbf{c}=\mathrm{High}$ dose group (400 mg/kg), d = Standard 
concentration. Hence, it has proved that the extract produced dose depended protection against CPL and CFA induced arthritis as shown in Fig. 3 and Fig. 4, respectively.

\section{Discussion}

The present study was performed to carryout the phytochemical screening of the dried fruit extracts of $M$. annua and to evaluate its in vitro and in vivo pharmacological activities. Herbal drugs possess several active constituents that are responsible for antiinflammatory activity $[41,42]$. The qualitative analysis of the sample exhibited the presence of secondary metabolites such as flavonoids, alkaloids, steroids, tannins, saponins and glycosides. Similar compounds were identified by Muazzam et al., 2018 in their study [43]. The fruit extract also exhibited antioxidant potential. The ethanolic extract showed maximum extent of total antioxidant activity as well as hyalurinodase inhibition. The phenolic compounds and flavonoids were believed to be responsible of antioxidant activities. Our results were in agreement with the findings of Arshad et al., 2017 [44]. The researchers reported the antioxidant activity of $M$. annua fruit extract was dose dependent. Herbal drugs are more safer than the synthetic drugs due to several toxicities associated with them [45-52]. Similarly in case of hyalurinodase inhibition assay, the extract was screened at three different concentrations such as $10 \mu \mathrm{l}, 50 \mu \mathrm{l}$ and $100 \mu \mathrm{l}$. To evaluate the anti inflammatory potential of the $M$. annua extract at different concentrations CPL induced paw edema model in rats was selected. The result of anti inflammatory potential of extract exhibited that the extract at higher concentration possess maximum reduction in paw edema at $6 \mathrm{~h}$ i.e. 65.33 , where as the standard drug ibuprofen exhibited 60.08 at $6 \mathrm{~h}$. The arthritis in animals was induced by injection of CFA intraarticularly. The result of anti-arthritic activity revealed that theextract at higher concentration exhibited

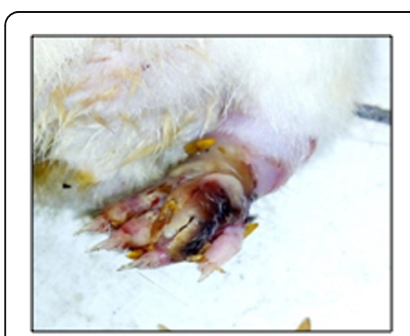

A

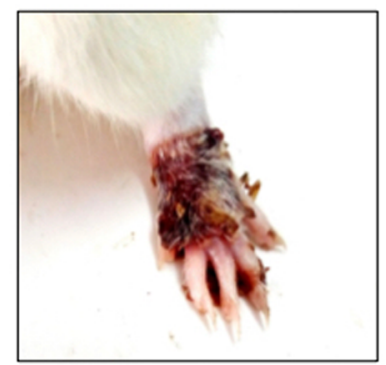

A

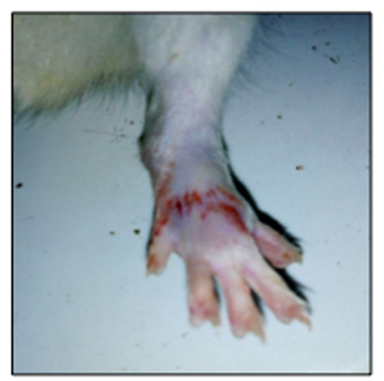

A

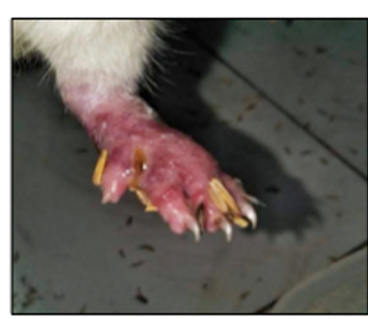

B

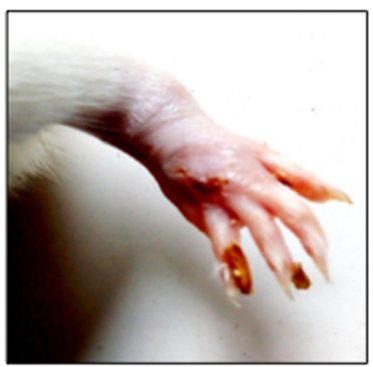

B

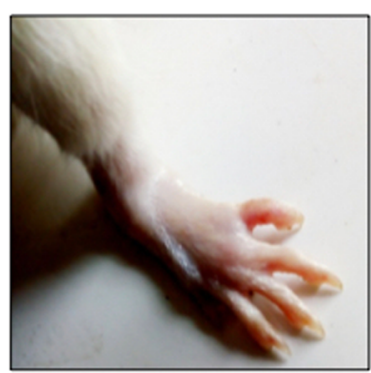

B

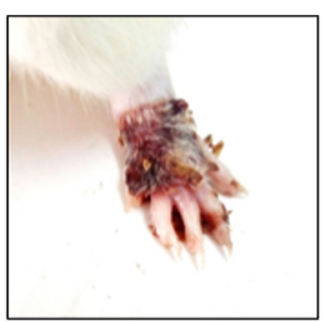

C

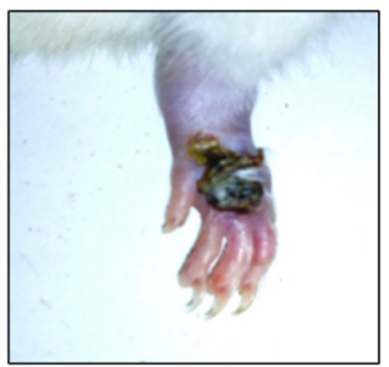

C

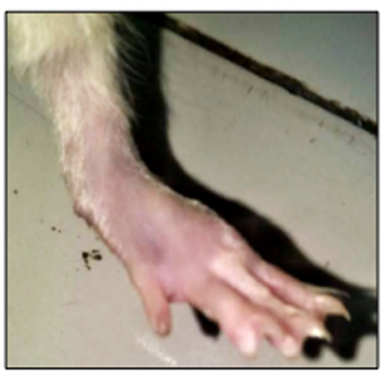

C
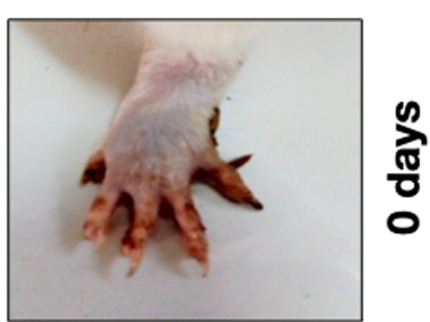

D

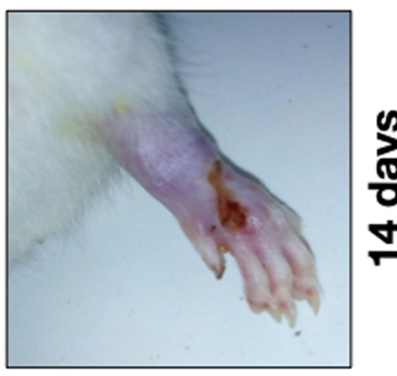

D

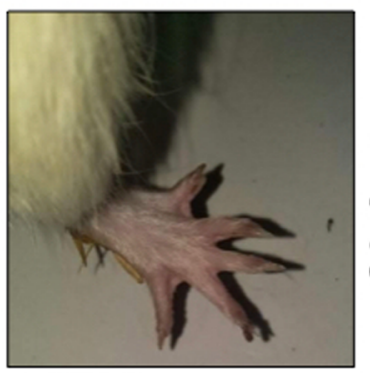

D

Fig. 3 X-ray images of CPL induced paw edema in rats. $\mathbf{a}=$ Control group, $\mathbf{b}=$ Low dose group $(200 \mathrm{mg} / \mathrm{kg})$, $\mathbf{c}=$ High dose group $(400 \mathrm{mg} / \mathrm{kg}), \mathbf{d}=$ Standard 


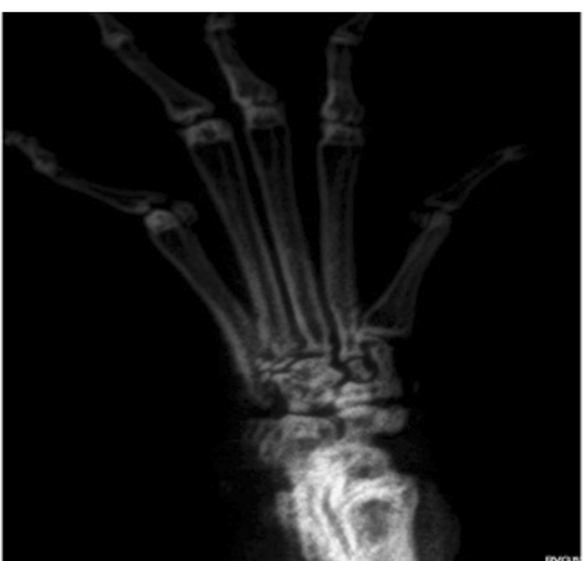

A

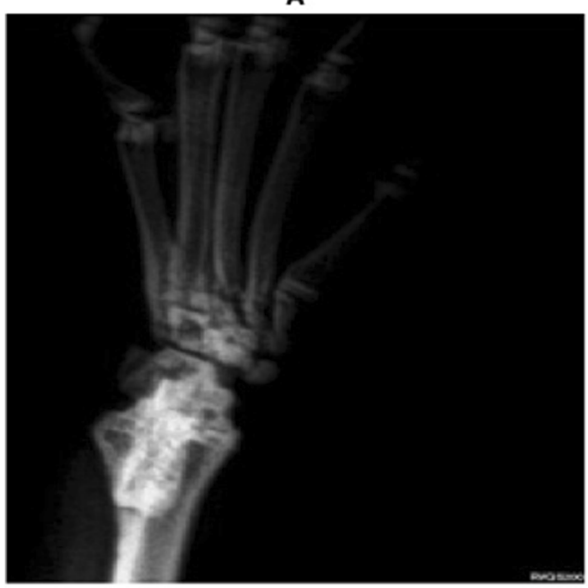

C

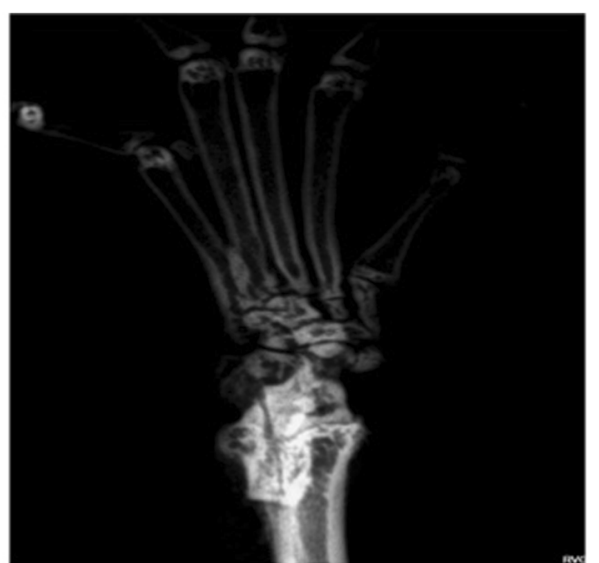

B

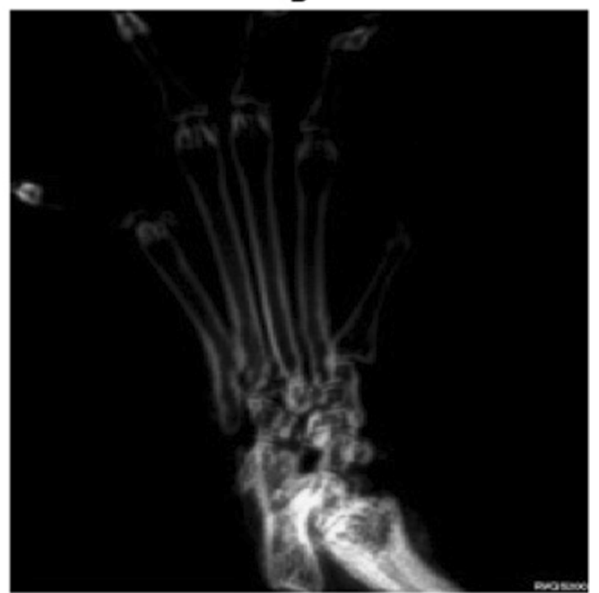

D

Fig. 4 X-ray images of CFA induced paw edema in rats. $\mathbf{a}=$ Control group, $\mathbf{b}=$ Low dose group $(200 \mathrm{mg} / \mathrm{kg}), \mathbf{c}=$ High dose group $(400 \mathrm{mg} / \mathrm{kg}), \mathbf{d}=$ Standard

maximum protection i.e. 64.28 as compared to control group. The anti-inflammatory and anti arthritic activities of herbal extract in our study were also supported by the work of Foyet et al., 2014 based on their study on Vitellaria paradoxa stem bark extract against inflammation and arthritis [53]. Chandel et al., 2013, reported that fruit extract of plants possess significant anti-arthritic activity [54].

\section{Conclusion}

It has evident from the study that $M$. annua extract possess both antioxidant and hyalurinodase inhibition activity at dose dependent manner as well as anti-arthritic and anti-inflammatory potential. Further, research at molecular level as well as clinical study using human volunteers will pave the way to establish safety and effectiveness of such extract there by it can be formulated into suitable dosage form commercialization for the overall well being of the society.

\section{Acknowledgements}

The authors are helpful to the institute for providing all required facilities. We are grateful towards Probecell: Scientific Writing Services for proofreading and editing of the article.

\section{Authors' contributions}

SK- Manuscript writing and lab work, PJ - Proofreading and editing, TS Guidance, PP-Assistance in lab work, AR-Guidance. The author(s) read and approved the final manuscript.

\section{Funding}

No funding received.

Availability of data and materials It can be made available on request.

\section{Ethics approval and consent to participate}

The protocol was reviewed by the expert committee (IAEC),considered and approved (Approval No is CIP/IAEC/2017/103 and Regd.No.1321/PO/ReBi/S/ 10/CPCSEA, Dated 22/10/2014).

Consent for publication Not applicable. 


\section{Competing interests}

No competing interest.

\section{Author details}

${ }^{1}$ Columbia Institute of Pharmacy, Tekari, Near Vidhansabha, Raipur, Chhattisgarh 493111, India. ${ }^{2}$ Chhattrapati Shivaji Institute of Pharmacy, Durg, Chhattisgarh, India.

Received: 26 July 2020 Accepted: 11 January 2021

Published online: 16 January 2021

\section{References}

1. Arnett FC, Edworthy SM, Bloch DA, McShane DJ, Fries JF, Cooper NS, Healey LA, Kaplan SR, Liang MH, Luthra HS. The American rheumatism association 1987 revised criteria for the classification of rheumatoid arthritis. Arthritis Rheum. 1988;31(3):315-24.

2. Mcllvane JM, Baker TA, Mingo CA. Racial differences in arthritis-related stress, chronic life stress, and depressive symptoms among women with arthritis: a contextual perspective. J Gerontol B Psychol Sci Soc Sci. 2008;63(5):320-7.

3. Lespasio MJ, Piuzzi NS, Husni ME, Muschler GF, Guarino A, Mont MA. Knee osteoarthritis: a primer. Perm J. 2017;21:1-7.

4. Winter CC, Brandes M, Müller C, Schubert T, Ringling M, Hillmann A, Rosenbaum D, Schulte TL. Walking ability during daily life in patients with osteoarthritis of the knee or the hip and lumbar spinal stenosis: a cross sectional study. BMC Musculoskelet Disord. 2010;11:233.

5. Wheaton MT, Jensen $\mathrm{N}$. The ligament injury-osteoarthritis connection: the role of prolotherapy in ligament repair and the prevention of osteoarthritis. J Prolother. 2011;3(4):790-812.

6. Nicholson LB. The immune system. Essays Biochem. 2016;60:275-301.

7. Adaji EE, Ahankari AS, Myles PR. An investigation to identify potential risk factors associated with common chronic diseases among the older population in India. Indian J Community Med. 2017;42(1):46-52.

8. Neogi T. The epidemiology and impact of pain in osteoarthritis. Osteoarthr Cartil. 2013;21(9):1145-53.

9. Abhishek A, Michael D, Chang-Fu K, Mallen CD, Zhang W, Grainge MJ. Rheumatoid arthritis is getting less frequent results of a nationwide population-based cohort study. Rheumat. 2017;56(5):736-44.

10. Benjamin O, Bansal P, Goyal A. Disease modifying anti-rheumatic drugs (DMARD). Treasure Island: StatPearls Publishing; 2020

11. Pandey MM, Rastogi S, Rawat AK. Indian traditional ayurvedic system of medicine and nutritional supplementation. Evid Based Complement Alternat Med. 2013;376327.

12. Ekor M. The growing use of herbal medicines: issues relating to adverse reactions and challenges in monitoring safety. Front Pharmacol. 2014;4:177.

13. Firenzuoli F, Gori L. Herbal medicine today: clinical and research issues. Evid Based Complement Alternat Med. 2007;4(1):37-40.

14. Rao SP, Jain P, Rathore P, Singh VK. Larvicidal and knockdown activity of Citrus limetta Risso oil against dengue virus vector. IJNPR. 2016;7(3):256-60.

15. Kumar V, Rathore K, Jain P, Ahmed Z. Biological activity of Bauhinia racemosa against diabetes and interlinked disorders like obesity and hyperlipidemia. Clin Phytoscience. 2017;3(1):7.

16. Sharwan G, Jain P, Pandey R, Shukla SS. Toxicity and safety profiles of methanolic extract of Pistacia integerrima J. L. Stewart ex Brandis (PI) for wistar rats. Aust J Pharm. 2016;19(3):253-8.

17. Kumar V, Jain P, Rathore K, Ahmed Z. Biological evaluation of Pupalia lappacea for antidiabetic, antiadipogenic, and hypolipidemic activity both in vitro and in vivo. Scientifica. 2016;1-9:1062430.

18. Jain P, Satapathy T, Pandey RK. Rhipicephalus microplus (acari: Ixodidae): Clinical safety and potential control by topical application of cottonseed oil (Gossypium sp.) on cattle. Exp Parasitol. 2020;1-7:108017.

19. Jain P, Satapathy T, Pandey RK. Efficacy of arecoline hydrobromide against cattle tick Rhipicephalus (Boophilus) microplus. Int J Acarol. 2020;46(4):268-75

20. Jain P, Satapathy T, Pandey RK. First report on ticks (Acari: Ixodidae) controlling activity of cottonseed oil (Gossypium Sp.). Int J Acarol. 2020; 46(4):263-7.

21. Jain P, Satapathy T, Pandey RK. Rhipicephalus microplus: a parasite threatening cattle health and consequences of herbal acaricides for upliftment of livelihood of cattle rearing communities in Chhattisgarh. Biocatal Agric Biotechnol. 2020;1-9:101611.
22. Rameshroo K, Prasad P, Satapathy T, Roy A. Martynia annua: an overview. UK J Pharm Biosci. 2013;1:7.

23. Usman $\mathrm{H}$, Abdulrahman F, Usman A. Qualitative phytochemical screening and in vitro antimicrobial effects of methanol stem bark extract of Ficus thonningii (Moraceae). Afr J Tradit Complement Altern Med. 2009;6(3):289-95.

24. Pandey R, Shukla S, Vyas A, Jain V, Jain P, Saraf S. Fingerprinting analysis and quality control methods of herbal medicines. Boca Raton: CRC Press; 2018.

25. Ezeonu CS, Ejikeme CM. Qualitative and quantitative determination of phytochemical contents of indigenous nigerian softwoods. New J Sci. 2016; 1-9:5601327.

26. Zaki M, Fadilah N, Rashid A. Preliminary phytochemical screening of polysaccharides content for selection of high quality planting materials : Eurycoma longifolia. Jurnal Teknologi. 2015;77(24):101-5.

27. Gaffar MK, Hassan LG, Dangoggo SM, Adams I. Amino acid estimation and phytochemical screening of Indigofera Astragolina leaves. J Chem Pharm Res. 2010;2(5):277-85.

28. Pooja S, Gm V. Phytochemical screening for secondary metabolites of Opuntia dillenii haw. J Med Plants Stud. 2016;4(5):39-43.

29. Pochapski MT, Fosquiera EC, Esmerino LA, Dos Santos EB, Farago PV, Santos FA. Phytochemical screening, antioxidant, and antimicrobial activities of the crude leaves' extract from Ipomoea batatas (L.) lam. Pharmacogn Mag. 2011; 7(26):165-70.

30. Hossain MA, AL-Raqmi KAS, AL-Mijizy ZH, Weli AM, Al-Riyami Q. Study of total phenol, flavonoids contents and phytochemical screening of various leaves crude extracts of locally grown Thymus vulgaris. Asian Pac J Trop Biomed. 2013;3(9):705-10,

31. Gul R, Jan SU, Faridullah S, Sherani S, Jahan N. Preliminary phytochemical screening, quantitative analysis of alkaloids, and antioxidant activity of crude plant extracts from Ephedra intermedia indigenous to Balochistan. Sci World J. 2017;1-7:5873648.

32. Auwal MS, Saka S, Mairiga IA, Sanda KA, Shuaibu A, Ibrahim A. Preliminary phytochemical and elemental analysis of aqueous and fractionated pod extracts of Acacia nilotica (thorn mimosa). Vet Res forum an Int Q J. 2014; 5(2):95-100.

33. Ahmad S, Ahmad S, Bibi A, Ishaq MS, Afridi MS, Kanwal F. Phytochemical analysis, antioxidant activity, fatty acids composition, and functional group analysis of Heliotropium bacciferum. Sci World J. 2014;1-8:829076.

34. Roopalatha UC, Nair VM. Phytochemical analysis of successive reextracts of the leaves of moringa. Int J Pharm Pharm Sci. 2013;5(3):629-34.

35. Delowar H, Shahid S, Syed Masudur RD, Shohel H. Shahid-Ud-Daula, Mohammad SI. Investigation of total phenolic content and antioxidant activities of Azadirachta indica roots. Avicenna J Phytomed. 2014;4(2):97-102.

36. Meenakshi SC, Beldal BS, Londonkar RL. Evaluation of methanolic extract of Bombax ceiba bark for in-vitro antioxidant and antiinflammatory activities. J Pharmacogn Phytochem. 2019;8(1):1504-7.

37. Kori P, Alawa P. Antimicrobial activity and phytochemical analysis of Calotropis gigantea root, latex extracts. IOSR J Pharm. 2014;4(6):7-11.

38. Yatin MS, Vijay LK. Histamine mediates the proinflammatory effect of latex of Calotropis procera in rats. Mediat Inflamm. 2003;12(5):299-302.

39. Omnia A, Mohamed Abdel EG, Amira Mourad AY, Ali AA. Effect of losartan in complete freund's adjuvant -induced arthritis in rats. Iran J Pharm Res. 2018;17(4):1420-30.

40. Ben IO, Woode E, Koffuor GA, Boakye-Gyasi E, Titiloye NA. Effect of Trichilia monadelpha (Meliaceae) extracts on bone histomorphology in complete Freund's adjuvant-induced arthritis. J Intercult Ethnopharmacol. 2017;6(2):177-85.

41. Jain P, Pandey R, Shukla SS. Inflammation: Natural resources and its applications. Springer Briefs, Springer Publications; 2015.

42. Jain P. Secondary metabolites for antiulcer activity. Nat Prod Res. 2016;30(6): 640-56

43. Muazzam S, Harvey J, Devièse T, Farman M, Mccullagh J. Targeted and untargeted metabolite profiling of the ethnobotanical Martynia annua L. identifies bioactive compounds with medicinal properties. Planta Medica Int Open. 2018;5:68-78.

44. Arshad Z, Saied S, Naz S. Antioxident activities and phytochemical screening of Martynia Annua fruit extract. Biosci Biotech Res Asia. 2017;14:1-4.

45. Rathore P, Rao SP, Roy A, Satapathy T, Singh V, Jain P. Hepatoprotective activity of isolated herbal compounds. Research J Pharm Tech. 2014;7(2):229-34.

46. Rao SP, Amrit I, Jain P, Singh V. Antiulcer activity of agnimukha churna. Int J Ayur Pharma Research. 2014;2(2):40-6. 
47. Jain P, Rao SP, Singh V, Pandey R, Shukla SS. Acute and sub-acute toxicity studies of an ancient Ayurvedic formulation: Agnimukha Churna. CJPS. 2014; 1(1):18-22.

48. Singh P, Jain P, Pandey R, Shukla SS. Phytotherapeutic review on diabetes. Spatula DD. 2016;6:2

49. Jain P, Pandey R, Shukla SS. Reproductive and developmental toxicity study of talisadya churna: an ancient polyherbal formulation. IAJPR. 2016;6(5): 5641-53.

50. Jain P, Pandey R, Shukla SS. Acute and subacute toxicity studies of polyherbal formulation talisadya churna in experimental animal model. MJPMS. 2015;1(1):7-10.

51. Sharwan G, Jain P, Pandey R, Shukla SS. Toxicity profile of traditional herbal medicine. J Ayu Herb Med. 2015;1(3):81-90.

52. Rao SP, Amrit I, Singh V, Jain P. Antiulcer activity of natural compounds: a review. J Pharmacogn Phytochem. 2015;7(2):124-30.

53. Foyet HS, Tsala DE, Zogo Essono Bodo JC, Carine AN, Heroyne LT, Oben EK. Anti-inflammatory and anti-arthritic activity of a methanol extract from Vitellaria paradoxa stem bark. Pharm Res. 2014;7(4):367-77.

54. Chandel HS, Singh S, Kushwaha R. Evaluation of antiarthritic activity on Luffa echinata Roxb fruits on rats. Asian J Biomed Pharm. 2013;3(21):36-41.

\section{Publisher's Note}

Springer Nature remains neutral with regard to jurisdictional claims in published maps and institutional affiliations.

\section{Submit your manuscript to a SpringerOpen ${ }^{\circ}$ journal and benefit from:}

- Convenient online submission

- Rigorous peer review

- Open access: articles freely available online

High visibility within the field

- Retaining the copyright to your article

Submit your next manuscript at $\boldsymbol{\nabla}$ springeropen.com 